University of Tennessee Health Science Center UTHSC Digital Commons

Spring 4-2019

\title{
An Assessment of Utilization of Prescription Anti-Hypertension Medications via a Health Records Database
}

Ryan Payne

University of Tennessee Health Science Center

Follow this and additional works at: https://dc.uthsc.edu/hiimappliedresearch

Part of the Health and Medical Administration Commons, and the Health Information Technology Commons

\section{Recommended Citation}

Payne, Ryan, "An Assessment of Utilization of Prescription Anti-Hypertension Medications via a Health Records Database" (2019). Applied Research Projects. 63. . https://doi.org/10.21007/chp.hiim.0060 https://dc.uthsc.edu/hiimappliedresearch/63

This Research Project is brought to you for free and open access by the Department of Health Informatics and Information Management at UTHSC Digital Commons. It has been accepted for inclusion in Applied Research Projects by an authorized administrator of UTHSC Digital Commons. For more information, please contact jwelch30@uthsc.edu. 
An Assessment of Utilization of Prescription Anti-Hypertension Medications via a Health Records

\section{Database}

Ryan Payne

PharmD/MHIIM Candidate

The University of Tennessee Health Science Center

Master's of Health Informatics and Information Management

Advisor: Dr. Madlock-Brown, Ph.D.

April 2019 
AN ASSESSMENT OF UTILIZAITON OF PRESCRIPTION

\section{Acknowledgements}

I would like to express my genuine appreciation to the dean and faculty of The University of Tennessee Health Science Center, The College of Health Sciences, and the department of Health Informatics and Information Management. I would also like to thank the College of Pharmacy. I am grateful to be a candidate for the dual degree PharmD/MHIIM. Most importantly, I would like to recognize my family for their continued support. Your time, patience and motivation has been my biggest motivation.

Thank you. 


\begin{abstract}
Obesity is a growing problem in the United States, though not a new one. It was estimated that over 72 million U.S. adults alone have a diagnosis of obesity. Among all preventable premature deaths, obesity ranks as the second leading cause. Contemporary classifications define obesity as a body mass index (BMI) greater than or equal to 30 . Several common comorbidities are widely present in obese populations, particularly hypertension, diabetes, and hyperlipidemia. Among these chronic disease states, hypertension has been identified as the most common and earliest identifiable. The purpose of this study was to make inferences on the prescribing of antihypertension medications in an obese population, as well as the associated cost of said medications. Cerner's Health Facts Library, a health records library that contains de-identified patient information was employed for this study. Structured Query Language (SQL) was used to design tables that incorporated all relevant and necessary information for analysis of the study question. The results of this study showed that ACE inhibitors were the most commonly prescribed blood pressure lowering class of medication in this obese population. Of this class, the ACE inhibitor lisinopril was the most commonly prescribed. Lisinopril was also identified as the cheapest ACE inhibitor.
\end{abstract}


Background

Purpose

Significance

Research Question

Limitations

Chapter 2 Review of Literature

Chapter 3

Methodology

Research Design

Population and Sample Design

Data Collection

Data Collection Instrument

Chapter 4 . Results

Chapter 5. .Conclusions and Recommendations

Future Studies

Table 1. Weight Classifications by Body Mass Index (BMI)... Page 4

Table 2. Relevant Current Literature. Page 7

Table 3. Patient Demographics. Page 9 
AN ASSESSMENT OF UTILIZAITON OF PRESCRIPTION

Table 4. Combination First Line Antihypertensive Agents

Page 10

Table 6. Unit Price of ACE-Inhibitors.....................................................Page 12

Figure 1. Top 40 Most Commonly Prescribed Drugs in the United States..Page11 
AN ASSESSMENT OF UTILIZAITON OF PRESCRIPTION

\section{Chapter 1}

Introduction

The prevalence of obesity, classified as a BMI greater than 30 (Table 1), has reached epidemic proportions. A study by Ogden et al. estimated that over 72 million US adults alone have a diagnosis of obesity (Ogden et al. 2007). Additionally, among all preventable premature deaths, obesity ranks as the second leading cause, with smoking holding on to the number one spot (Stein \& Colditz, 2004). However, some experts have predicted that obesity may soon replace smoking as the leading cause of preventable deaths in the United States. Since the World Health Organization (WHO) classified obesity as a disease, various initiatives have been implemented to attempt to tackle the growing issue of obesity. However, the prevalence has not decreased, and therefore, remains an important public health agenda (WHO, 2016). Interestingly, the prevalence of obesity differs by sex, age, and socioeconomic status, with a rapid increase in the occurrence of obesity among younger populations and those of lower socioeconomic status. Obesity has been and continues to be a major public health issue both in itself and as a result of its association with the development of several chronic comorbidities $(\mathrm{NIH}, 2006)$.

The steady increase in the prevalence of obesity has created a growing need and demand for a more in-depth focus on preventable cardiovascular diseases. Such initiatives would target the most common comorbidities associated with obesity. Such initiatives would also pay special attention to disease states such as diabetes mellitus, hyperlipidemia, and hypertension. This is because obesity is associated with an increased incidence of cardiovascular disease, type 2 diabetes mellitus, hypertension, stoke, dyslipidemia (hyperlipidemia), osteoarthritis, and some cancers (Burton et al. 2005). Of the top three comorbid conditions, diabetes, hyperlipidemia, and hypertension, hypertension is the most common. 
AN ASSESSMENT OF UTILIZAITON OF PRESCRIPTION

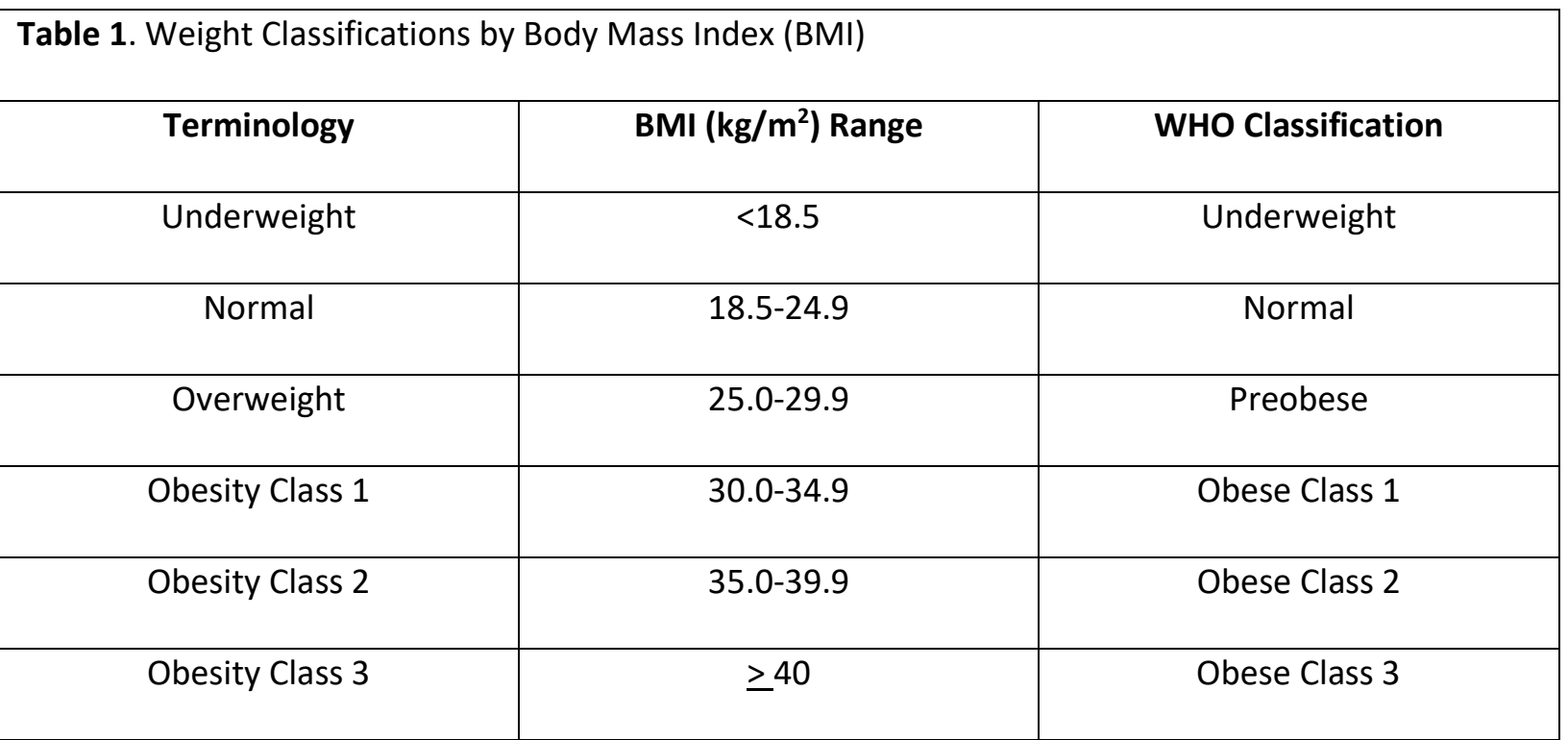

\section{Background of Problem}

A study published by Wang and Ling in 2008 looked at the cost and prevalence of obesity in the United States and found some interesting results. This study found that the annual spending related to obesity and its associated comorbidities was estimated at $\$ 315.8$ billion dollars in 2010 , accounting for 27.5\% of the United States healthcare expenditure. Additionally, they concluded that costs related to being overweight or obese are projected to reach $\$ 861$ billion dollars by 2030 (Wang and Ling, 2008). This is a significant portion of U.S. healthcare cost and therefore warrants a closer analysis. This led us to breakdown the numbers and assess the role that medications play in contributing to the rising cost of care for obese populations, and any implications that may be revealed by what was find.

\section{Purpose of Study}

With the idea of the enormous cost associated with care for obese and overweight populations in mind, we wanted to determine the role that prescription medications played in contributing to the overall cost and burden of obesity on the U.S. healthcare system. This study determined the most common comorbid conditions associated with obesity and broke them down further into the most common and earliest identifiable comorbid condition. This was found to be hypertension. The aim of 
AN ASSESSMENT OF UTILIZAITON OF PRESCRIPTION

this study was to determine which hypertension medications were most commonly prescribed in obese patients, the cost associated with each and to infer how medication cost affects the delivery and quality of care administered.

\section{Significance of Study}

The focus of this study, as mentioned above, is to determine the most frequently, and most expensive hypertension medications prescribed. This study is important because the prevalence of obesity is at an all time high in the United States and continues to grow. This study breaks down the most frequently prescribed hypertension medications and assess the cost associated with each. This is significant because hypertension is the most common comorbid condition associated with obesity, as well and the earliest identifiable risk factor. By indirectly assessing prescribing, and cost, we can draw inferences and make associations between the medications prescribed, disease progression, and compare the most updated treatment guidelines with what is actually being prescribed. This type of analysis has the ability to generate hypothesis and shed light on any inconsistencies.

In addition to the aforementioned, this research has the ability to affect populations at risk for obesity. This is important, because the cost associated with obesity in 2010 was at $\$ 315.8$ billion dollars, and it is estimated that the cost will be $\$ 861$ billion dollars by 2030 (Wang and Ling, 2008). By shedding light on cost, and prescribing, and comparing that to current recommended evidence-based treatment guidelines, this study can generate discussion on the way hypertension in currently managed in the obese.

\section{Research Questions}

As mentioned above, the questions that this paper aims to answer are important ones. These include determining which hypertension medications are most commonly prescribed (occur the most 
AN ASSESSMENT OF UTILIZAITON OF PRESCRIPTION

frequently) and determining which hypertension medications are the most expensive. To answer these questions, this study relied on Cerner's Health Facts ${ }^{\circledR}$ Database. This database captures and stores deidentified, longitudinal electronic health record (EHR) patient data, and then aggregates and organizes these data into consumable data sets to facilitate analysis and reporting. The data are generated from Cerner and non-Cerner participating contributing facilities and go back as far as 2000 (USC, 2017). For the purposes of this paper, we will only review the calendars years of 2016 and 2017 due to the lack of manpower and resources to analyze larger amounts of data. Oracle will be used to create queries that allow us to analyze the data in Cerner's database. Simple queries will be written that identify the most commonly prescribed medications for the time period that we are interested in. This information will be broken down further to analyze the cost of each hypertension medication. By doing this, it will allow for analysis of prescribing and cost. With this information, inferences can be made regarding the delivery of care as well as how evidence-based and appropriate the care is.

\section{Definition of Terms}

Antihypertensives - A class of medications used to treat hypertension (high blood pressure). The goal of this therapy is to prevent the complications associated with prolonged high blood pressure.

Angiotensin Converting Enzyme Inhibitor (ACE Inhibitor) - A class of antihypertensive medications that lower blood pressure by inhibiting the enzyme, ACE.

Calcium Channel Blocker (CCB) - A class of antihypertensive medications that lower blood pressure by antagonizing the movement of calcium through calcium channels.

Total Charges - The total charges for an encounter. Total Charges includes both covered and non-covered charges.

Unit Price - The price per dose for inpatient orders, or the price of the entire quantity for outpatient orders. 
AN ASSESSMENT OF UTILIZAITON OF PRESCRIPTION

\section{Limitations}

As with every research study, there are limitations. Because this research question relies on information entered into an electronic health record, the data is only as accurate as it was entered. Inaccurate entries and coding are two limitations of this study. Additionally, not all relevant information may have been available for analysis due to clerical entering and editing. Additional limitations include the fact that this study only assess the years of 2016 and 2017 leading to a smaller sample size. This may limit external validity.

\section{Chapter 2}

\section{Review of Literature}

This section will focus on how the literature was obtained, as well as a brief history on the current research question, with a focus on past, and present literature. Each article referenced in this study will be briefly reviewed and related to the overall purpose of this study.

Search engines employed in this literature review included PubMed, Google Scholar, and the Cochrane Library. Terms such as "obesity" "hypertension" "comorbidities" "obesity disease burden" and "pharmacoeconomics of obesity" were all used to begin the literature search. Of the literature search engines above, PubMed provided the most relevant results, and therefore, provided the most articles included in this paper. Google Scholar provided the broadest information sources and set a solid foundation that allowed for better understanding of the subject. Articles included in this paper were not limited by date published. To further narrow the search, articles had to be US-based, of high-quality study design, and contain large sample sizes. No case-controlled studies were included in this paper. Once the most relevant articles were identified, they were analyzed for accurateness. Of the top 15 most relevant articles identified, 2 were studied in a Korean population, 1 included a UK population sample, 1 was a poorly designed case study and 1 included a handicap population consisting of paraplegics and quadriplegics. As a result, only 10 articles were included in the final analysis. As 
AN ASSESSMENT OF UTILIZAITON OF PRESCRIPTION

mentioned earlier, publication dates were not limited. This was done to provide historical context and reference for the researchers and audience.

To provide historical reference, literature on the topic of obesity and the disease burden associated with it is vast and thorough. This includes classification of obesity, disease progression, associated comorbidities, predisposing factors, prevalence, genetic associations, pharmacoeconomic analysis, and medications used to treat, among many others. However, despite all of the research done on this topic, there is a limited amount of studies that breakdown the most commonly prescribed medications and assess the associated cost and prescribing. Furthermore, there are even fewer studies that assess specific classes of medications (i.e. antihypertensives). A 1993 study by Schmieder, Gatzka, Schächinger, Schobel, and Rüddel looked at the use of different types of antihypertensives in obesity, with the hypothesis that beta blockers are more effective in this population than calcium channel blockers. They believed that calcium channel blockers would be more effective in a non-obese population (Schmieder et al. 1993). While not identical to this study, this is one of the few studies that assess the use of different hypertensive medications in the obese populations. Unfortunately, it is an old article.

Current literature on this topic is very limited (Table 2). Two of the larger, more complete studies, one a randomized controlled trial by Nedogoda et al., and the other being a systemic review by Owen and Reisin shed light on this topic and have been referenced numerous times. Outside of the studies outlined in Table 2, not many have assessed antihypertensive medications as it pertains to prescribing and cost, from an electronic health record such as the Health Facts Database. This is one reason that this study is unique. As demonstrated in Table 2, current literature focuses on determining which medications are most appropriate and/or effective in obese patients, and treatment of hypertension in obesity. 
AN ASSESSMENT OF UTILIZAITON OF PRESCRIPTION

\begin{tabular}{|c|c|c|c|}
\hline \multicolumn{4}{|c|}{ Table 2. Relevant Current Literature } \\
\hline Authors & Article Title & Population & Year Published \\
\hline Owen \& Reisin & $\begin{array}{l}\text { Anti-hypertensive Drug Treatment of } \\
\text { Patients with and the Metabolic } \\
\text { Syndrome and Obesity: A Review of } \\
\text { Evidence, Meta-Analysis, Post hoc and } \\
\text { Guidelines Publications }\end{array}$ & $\begin{array}{l}\text { ad hoc studies, prospective } \\
\text { studies, and guideline } \\
\text { publications }\end{array}$ & 2015 \\
\hline Landsberg et al. & $\begin{array}{c}\text { Obesity-Related Hypertension: } \\
\text { Pathogenesis, Cardiovascular Risk, and } \\
\text { Treatment }\end{array}$ & $\mathrm{N} / \mathrm{A}$ & 2013 \\
\hline Nedogoda et al. & $\begin{array}{c}\text { Randomized Trial of Perindopril, } \\
\text { Enalapril, Losartan and Telmisartan in } \\
\text { Overweight or Obese Patients with } \\
\text { Hypertension }\end{array}$ & $\begin{array}{c}120 \text { overweight or obese } \\
\text { patients (body mass index } \\
\geq 27 \mathrm{~kg} / \mathrm{m}^{2} \text { ) with hypertension }\end{array}$ & 2013 \\
\hline Schmieder et al. & $\begin{array}{l}\text { Obesity as a Determinant for Response } \\
\text { to Antihypertensive Treatment. }\end{array}$ & N/A & 1993 \\
\hline
\end{tabular}

\section{Chapter 3}

\section{Methodology}

The purpose of this section is to detail the methods performed and steps taken to complete this research project. In this section, the reader can expect to find in-depth statements on the research design, the research population, as well as their demographics and how this population was chosen, indepth explanations on how data was collected, any collection instruments employed as well as their development process, and lastly, an explanation of data analysis. This chapter will be concluded with a summary of everything discussed.

\section{Research Design}

This study used information entered into Cerner's Health Facts Library. This library contains a plethora of de-identified patient information and allowed for the analysis of the study question.

\section{Population and Sample Design}

The purpose of this study was to make inferences on the prescribing of antihypertension medications in an obese population via frequency of occurrences in the database, as well as the associated cost of these medications. With such a question, the population must meet specific 
AN ASSESSMENT OF UTILIZAITON OF PRESCRIPTION

requirements. This study employed an obese population with multiple comorbid conditions. Patients were retrospectively selected based on records from Cerner's Health Facts Database. Those selected had a BMI of 30 or greater, were 18 years or older, and had to have a clinical diagnosis of hypertension. Patients also had to be on at least one prescription antihypertensive medication. Patients were excluded if they had a diagnosis of obesity, but no history of hypertension, had a diagnosis of hypertension but no prescription antihypertensive medications, or had an BMI greater than 70. This BMI cutoff was based on the National Institute of Health's BMI chart that includes BMIs through 60 . While a $\mathrm{BMI}$ greater than 70 is not uncommon, BMIs that high are more prone to charting errors. This population was selected because they provided the most relevant characteristics for the question at hand. This population would allow for answering of the question as well as further analysis of any postanalysis questions. Patient demographic breakdown is included in Table 3.

\begin{tabular}{|l|l|l|l|}
\hline \multicolumn{2}{|c|}{ Age \& BMI } & \multicolumn{2}{c|}{ Race and Ethnicity (n=39,844) } \\
\hline Average Age & 59 & Caucasian & $90.8 \%$ \\
\hline Most Common Age & 67 & African American & $5.4 \%$ \\
\hline Average BMI & 34 & Asian & $0.065 \%$ \\
\hline Most Common BMI & 30.7 & Pacific Islander & $0.005 \%$ \\
\hline \multicolumn{1}{|c|}{ Gender } & & Native American & $3.1 \%$ \\
\hline Male & $41.1 \%$ & Asian/Pacific Islander & $0.07 \%$ \\
\hline Female & $58.8 \%$ & Other/Unknown/Not Mapped & $0.51 \%$ \\
\hline
\end{tabular}


AN ASSESSMENT OF UTILIZAITON OF PRESCRIPTION

\section{Data Collection}

Data for this study was collected retrospectively via Cerner's Health Facts Database. Structured Query Language (SQL) was used to design tables that incorporated all relevant and necessary information. The final table included age, total charges (the cost for the encounter, which includes covered and non-covered charges), BMI, year, patient sk (a unique blinded person identifier), medication brand and generic names, and drug classification. Information from this table allowed for the identification of hypertensive medications.

\section{Data Collection Instrument}

Cerner's Health Facts Database was employed for the purposes of data collection in this study. Structured Query Language was used to create queries and tables that contained all relevant and necessary information

\section{Results}

This purpose of this chapter is to discusses the results of this study as well as the generalizability of said results.

In this study, angiotensin converting enzyme (ACE) inhibitors were identified as the most common antihypertensive medication prescribed (it occurred the most often) to this obese population. According to data released from the Department of Pharmaceutical Sciences within the College of Pharmacy at Larkin University in conjunction with the Centers for Disease Control and Prevention Institute, it is also the most common blood pressure lowering medication prescribed to non-obese populations as well (Figure 1).

The average age of this population was 59 , with an average BMI of 34 , classifying this population as obesity class 1 . When all ACE inhibitors were examined, lisinopril (Prinivil ${ }^{\circledR}$, Zestril ${ }^{\circledR}$ ) occurred the most often. This insinuates that, in this population, lisinopril was prescribed the most often. Other ACE 
inhibitors included enalapril, accupril, and captopril. When cost of each agent was assessed, the total charges was highest when associated with lisinopril. Because lisinopril is prescribed more than other ACE inhibitors, it has a greater chance of being associated with a more expensive encounter, when compared to other similar medications. We do not believe that the addition of lisinopril contributes to a more expensive encounter. This hypothesis is consistent with what was seen when unit price was analyzed. When unit price was assessed, lisinopril was the cheapest, on average (Table 6).

When the results of this study was compared to The American College of Cardiology and American Heart Association (ACC/AHA) Hypertension Treatment Guidelines, it appears that the study population received appropriate and evidence based care. These guidelines are used nationally and internationally and set the standards for care of patients with hypertension. They recommend the use of an ACE inhibitor, calcium channel blocker, thiazide diuretic, or angiotensin receptor blocker first line. As mentioned earlier, ACE inhibitors were the most common antihypertensive in our population. When combination first line agents were assessed the following in Table 4 was observed.

\begin{tabular}{|l|c|}
\hline \multicolumn{2}{|c|}{ Table 4. Combination First Line Antihypertensive Agents } \\
\hline ACE-I + Thiazide & $12 \%$ \\
\hline $20 \%$ & ACE-I CCB \\
\hline Most Commonly Prescribed Anti-Hypertensive In US (2018) \\
\hline \multicolumn{2}{|c|}{ 1. Lisinopril (ACE-I) } \\
7. Amlodipine (CCB) \\
11. Hydrochlorothiazide (Thiazide) \\
12. Losartan (ARB) \\
\hline
\end{tabular}


Figure 1. Top 40 Most Commonly Prescribed Drugs in the United States

\begin{tabular}{|c|c|c|c|c|c|c|c|c|c|}
\hline $\begin{array}{c}\text { Lisinopril } \\
A C E i \\
\text { Aatilinpertensive } \\
\text { PO } \\
\text { ADR: CV, CNS } \\
\text { BB: Preznancy }\end{array}$ & $\begin{array}{c}2 \text { Levothyroxine } \\
\text { Hypothyrouldism } \\
\text { PO } \\
\text { ADR:CV, CNs } \\
\text { BB; Weightless }\end{array}$ & 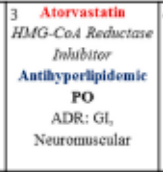 & \begin{tabular}{|c|}
4 Metformin \\
Biguanide \\
Antidlabetic \\
PO \\
ADR: GL, Diarthes \\
BB: L.actic \\
decidesis
\end{tabular} & 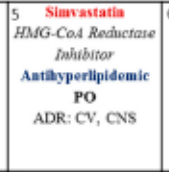 & \begin{tabular}{|cc}
6 Omeprazole \\
PPI \\
Aati-GERD \\
PO \\
ADR: Carcisoesa, \\
CDAD
\end{tabular} & $\begin{array}{|cc|}7 \quad \text { Amlodipine } \\
\text { Besylate } \\
\text { CCB } \\
\text { Aathlypertensive } \\
\text { PO } \\
\text { ADR: CV, } \\
\text { Respiranory }\end{array}$ & $\begin{array}{|cc|}8 & \text { Metoprolol } \\
& \text { Beta Blocker } \\
& \text { Antiliyperteasive } \\
& \text { PO } \\
\text { ADR: CV, Dermatologic } & \\
& \text { BB:CV }\end{array}$ & \begin{tabular}{|c|}
9 Acetsminophen: \\
Hydrocodome \\
Opioud \\
Analgesic \\
PO \\
ADR: CV, CNS \\
EB:Respiruten \\
Depression
\end{tabular} & $\begin{array}{l}\text { 10 Albuterol } \\
\text { Beta-2.Agonist } \\
\text { Bronehodilator } \\
\text { Inh. } \\
\text { ADR: Respiratory, } \\
\text { CNS }\end{array}$ \\
\hline $\begin{array}{c}11 \text { Hydrochlorothiazide } \\
\text { Dhiuretic } \\
\text { Antilitypertensive } \\
\text { PO } \\
\text { ADR: CV, Endocrine }\end{array}$ & 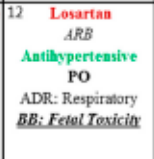 & $\begin{array}{c}13 \text { Gabapentin } \\
\text { Anticonvulsant } \\
\text { PO } \\
\text { ADR: CNS, Viral } \\
\text { infection }\end{array}$ & 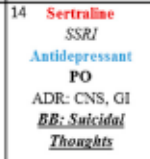 & 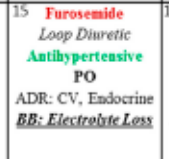 & $\begin{array}{c}16 \text { Acetaminophen } \\
\text { Analgesic } \\
\text { PO } \\
\text { ADR: Endosrite, } \\
\text { Renal } \\
\text { BBi:Hegatofoxicio }\end{array}$ & 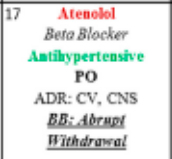 & $\begin{array}{|cc|}18 \text { Pravastatin } \\
\text { HMG-Cod Reductase } \\
\text { Inhibifor } \\
\text { Antihyperlipidemic } \\
\text { PO } \\
\text { ADR: CV, CNs }\end{array}$ & $\begin{array}{c}19 \text { Amosicillin } \\
\text { Antilisotic } \\
\text { PO } \\
\text { ADR: CV, Gl }\end{array}$ & $\begin{array}{c}20 \text { Fooxetine } \\
\text { SSRI } \\
\text { Antidepressant } \\
\text { PO } \\
\text { ADR: CNS, GI } \\
\text { BB; Suicidol } \\
\text { Thoughts }\end{array}$ \\
\hline $\begin{array}{c}21 \\
\text { Citalopram } \\
\text { SSRI } \\
\text { Antidepressant } \\
\text { PO } \\
\text { ADR: CNS, G1 } \\
\text { BB:Suicidal } \\
\text { Therghts }\end{array}$ & 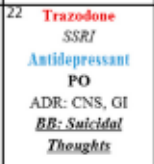 & $\begin{array}{l}23 \text { Alprazolam } \\
\text { Benzodiazepine } \\
\text { Antianciety } \\
\text { PO } \\
\text { ADR: CNS } \\
\text { BB: Concomitrant } \\
\text { with Opioids }\end{array}$ & $\begin{array}{cc}24 & \text { Fluticasone } \\
\text { Corticosteroid } \\
\text { Xasal } \\
\text { ADR: CNS }\end{array}$ & 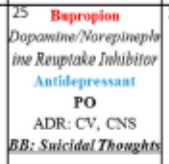 & $\begin{array}{l}26 \text { Carvediliol } \\
\text { Beta Blacher } \\
\text { Antillypertensive } \\
\text { PO } \\
\text { ADR: CV, CNS }\end{array}$ & $\begin{array}{c}27 \text { Potssinm Chloride } \\
\text { Electrolyte Sapplement } \\
\text { PO } \\
\text { ADR: Dermatologic, } \\
\text { Endocrine }\end{array}$ & $\begin{array}{|cc|}28 & \text { Tramadol } \\
\text { Opsoid } \\
\text { Assigesic } \\
\text { PO } \\
\text { ADR: CNS, G1 } \\
\text { BB: Respirutery } \\
\text { Depression }\end{array}$ & $\begin{array}{c}29 \text { Pantoprazole } \\
\text { PPI } \\
\text { Anti-OERD } \\
\text { PO } \\
\text { ADR: CNS }\end{array}$ & $\begin{array}{l}30 \text { Montelakast } \\
\text { Lemkoriene Recoptor } \\
\text { Anfagenist } \\
\text { Anti-asthmatic } \\
\text { PO } \\
\text { ADR: CNS, } \\
\text { Dermatologic }\end{array}$ \\
\hline $\begin{array}{cc}31 & \text { Escitalopram } \\
\text { SSRI } \\
\text { Antidepressant } \\
\text { PO } \\
\text { ADR: CNS, GI } \\
\text { BB:Snicidal } \\
\text { Thanghts }\end{array}$ & $\begin{array}{l}32 \text { Predaisome } \\
\text { Carticousteroid } \\
\text { Anti-inflammatory } \\
\text { Po } \\
\text { ADR: CV, Endocrime }\end{array}$ & \begin{tabular}{|l|}
33 Rosuvastatin \\
HMG-Co.4 Reductare \\
Inhubitor \\
Antihyperlipidemic \\
PO \\
ADR: Neuromuscular
\end{tabular} & $\begin{array}{c}\text { 34 Ibuprofen } \\
\text { NSAID } \\
\text { Analgesic } \\
\text { PO } \\
\text { ADR: CV, GI } \\
\text { BE: Thremberic } \\
\text { erents }\end{array}$ & $\begin{array}{c}35 \text { Melosicam } \\
\text { NSAID } \\
\text { Analgesic } \\
\text { PO } \\
\text { ADR: CNS, GI } \\
\text { BD: Thremberic } \\
\text { Enents }\end{array}$ & $\begin{array}{l}36 \text { Tosulia Glargine } \\
\text { Antidiabetic } \\
\text { Inj. } \\
\text { ADR: Primarily } \\
\text { Hypozlycemia }\end{array}$ & $\begin{array}{c}77 \text { Hydrochlorothiaride } \\
\text { \&: Lisinopril } \\
\text { ACEIDiuretic } \\
\text { Antilitypertensive } \\
\text { PO } \\
\text { ADR: CV, CNS } \\
\text { BB: Fetal Taxicity }\end{array}$ & $\begin{array}{|cc|}38 \text { Clonazepnum } \\
\text { Beszodiazeppine } \\
\text { Anticoavulsant } \\
\text { PO } \\
\text { ADR: CNS } \\
\text { BB: Cencomitantwith } \\
\text { Opioids }\end{array}$ & 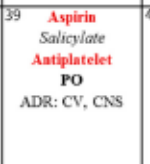 & $\begin{array}{c}00 \text { Clopidogrel } \\
\text { Antiplatelet } \\
\text { PO } \\
\text { ADR: Hematologic, } \\
\text { Dermatologic } \\
\text { EB: CXP2CO Poer } \\
\text { Metabolizer }\end{array}$ \\
\hline 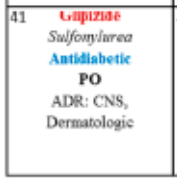 & \begin{tabular}{|c|}
42 Warturin \\
Anticongulant \\
PO \\
ADR: Hematologic, \\
CV \\
BB: Bleed Risk
\end{tabular} & $\begin{array}{l}\text { 43 Lycibbenzuphine } \\
\text { Muscle Relaxant } \\
\text { Amalgesic } \\
\text { PO } \\
\text { ADR: CNS, GI }\end{array}$ & $\begin{array}{l}44 \text { IIIsnim numan } \\
\text { Antidlabetic } \\
\text { Inj. } \\
\text { ADR: CV, } \\
\text { Eadocrine }\end{array}$ & $\begin{array}{l}\text { 43 } 1 \text { milisulabsin } \\
\text { Alpha- }- \text {-Antagonist } \\
\text { Urinary Retention } \\
\text { PO } \\
\text { ADR: CV, CNS }\end{array}$ & 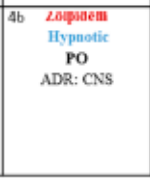 & 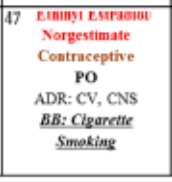 & 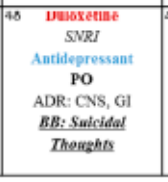 & $\begin{array}{l}\text { Raniballite } \\
\text { Histamine } H 2 \\
\text { Antagomist } \\
\text { Antiulcerant } \\
\text { PO } \\
\text { ADR: CV, CNS }\end{array}$ & $\begin{array}{c}\text { SO Ventumine } \\
\text { SNRI } \\
\text { Antidepressunt } \\
\text { PO } \\
\text { ADR: CNS, } \\
\text { Dermatologic } \\
\text { BE: Suicidol } \\
\text { Troughts } \\
\end{array}$ \\
\hline
\end{tabular}

Table 6. Unit Price of ACE Inhibitors

\begin{tabular}{|c|c|}
\hline ACE & Unit Price (\$) \\
\hline Accupril & 5.52 \\
\hline Captopril & $0.87-8$ \\
\hline Enalapril & $5-12.75$ \\
\hline Prinivil & $3-6$ \\
\hline Lisinopril & $0.8-13.65$ \\
\hline
\end{tabular}

\section{Chapter 5}

\section{Conclusions and Recommendations}

This chapter will reiterate the purpose of the study as well as highlight important points and connect supporting arguments. 
AN ASSESSMENT OF UTILIZAITON OF PRESCRIPTION

\section{Conclusions}

The results of this study, mentioned above, found that the ACE inhibitor lisinopril was the most commonly prescribed antihypertensive in the study populations. This is what is also seen outside of the study population in the real world. In fact, lisinopril was the most commonly prescribed medication in the United States in 2018 (Figure 1). ACE inhibitors were likely the most prescribed agent due to the numerous benefits outside of blood pressure lowering. In fact, in addition to lowering blood pressure, they also help protect the kidneys, decrease the risk of heart attack, decrease the risk of stroke, decrease all-cause mortality by $10 \%$ and decrease cardiovascular mortality by $12 \%$. Additionally, for individuals who have had a previous heart attack or stroke, ACE inhibitors have been shown to decrease reoccurrence. Why lisinopril in particular was the most commonly occurring ACE inhibitor is likely due to cost. When unit price was analyzed, it was cheapest for lisinopril (Table 6). However, this same analysis, when applied to the other ACE inhibitors, didn't hold true; number of occurrences wasn't positively correlated with cost. There are likely other underlying factors that are at play and further analysis is warranted to determine this lack of correlation. Considering the results and the conclusion, it does not appear that hypertension medications are contributing much to the overall healthcare expenditure. It should also be noted, however, that this information is a snapshot in time. Therapy progression and adverse effects that led to medication discontinuation, among other things, is unknown. It is important to keep this in mind when definitively determining therapy appropriateness.

\section{Recommendations}

ACE inhibitors are a class of antihypertensive medications that offer a range of benefits outside of lowering blood pressure. They are currently some of the most commonly prescribed blood pressure lowering medications. Based on the results and conclusions of this study, ACE inhibitors are being prescribed preferentially to other similar medications and should continue to be prescribed as such, given the cost and aforementioned benefits. 
AN ASSESSMENT OF UTILIZAITON OF PRESCRIPTION

Future studies should examine prescribing of DM and HLD medications in the obese with a similar focus of this study. This is timely and appropriate as there have been surges in the price of insulin, used to treat DM, in recent months. Additionally, cost should be assed based on region of the country. It has been well established that the south has higher rates of obesity than the west and northeast. Other areas of interest can focus on determining formulary status and figuring out how formulary designations affect guideline prescribing. 
AN ASSESSMENT OF UTILIZAITON OF PRESCRIPTION

\section{References}

Burton BT, Foster WR, Hirsch J, Vanltalle TB. Health Implications of Obesity; NIH consensus development conference. Int J Obesity Relat Metab Disord. 1985;9:155-169

Fuentes, A., Pineda, M., \& Venkata, K. (2018). Comprehension of Top 200 Prescribed Drugs in the US as a Resource for Pharmacy Teaching, Training and Practice. Pharmacy,6(2), 43. doi:10.3390/pharmacy6020043

Landsberg, L., Aronne, L. J., Beilin, L. J., Burke, V., Igel, L. I., Lloyd-Jones, D., \& Sowers, J. (2013). ObesityRelated Hypertension: Pathogenesis, Cardiovascular Risk, and Treatment. The Journal of Clinical Hypertension,15(1), 14-33. doi:10.1111/jch.12049

National Institute for Health and Clinical Excellence (2006). Obesity: the prevention, identification, assessment and management of overweight and obesity in adults and children. NICE Clinical Guidelines. London: National Institute for Health and Clinical Excellence (UK), 2006.

Nedogoda, S. V., Ledyaeva, A. A., Chumachok, E. V., Tsoma, V. V., Mazina, G., Salasyuk, A. S., \& Barykina, I. N. (2013). Randomized Trial of Perindopril, Enalapril, Losartan and Telmisartan in Overweight or Obese Patients with Hypertension. Clinical Drug Investigation,33(8), 553-561. doi:10.1007/s40261-013-0094-9

Ogden, C. L., Carroll, M. D., McDowell, M. A., \& Flegal, K. M. (2007). Obesity among adults in the United States-no statistically significant changes since 2003-2004. NCBS data brief no 1. Hyattsville, MD: National Center for Health Statistics.

Owen, J. G., \& Reisin, E. (2015). Anti-hypertensive Drug Treatment of Patients with and the Metabolic Syndrome and Obesity: A Review of Evidence, Meta-Analysis, Post hoc and Guidelines Publications. Current Hypertension Reports,17(6). doi:10.1007/s11906-015-0558-9 
AN ASSESSMENT OF UTILIZAITON OF PRESCRIPTION

R E Schmieder, C Gatzka, H Schächinger, H Schobel, H Rüddel (1993). Obesity as a Determinant for Response to Antihypertensive Treatment. BMJ 1993;307:537. doi: https://doi.org/10.1136/bmj.307.6903.537.

Stein, C. J., \& Colditz, G. A. (2004). The epidemic of obesity. The Journal of Clinical Endocrinology and Metabolism, 89, 2522-2525. doi: 10.1210/jc.2004-0288.

World Health Organization (WHO). Obesity and overweight. Fact sheet 2016.

http://www.who.int/mediacentre/factsheets/fs311/en/ 